\title{
KRITERIA TANAH TERLANTAR DALAM PERATURAN PERUNDANGAN INDONESIA
}

\author{
Supriyanto \\ Fakultas Hukum Universitas Jenderal Soedirman Purwokerto, Jawa Tengah
}

\begin{abstract}
When the State grants the person or legal entity is always accompanied by the obligations set forth in the BAL and the decision letter granting rights. Therefore prohibited from abandoning their land rights holders, and if the rights holders to abandon their land, the BAL has set the legal consequences of the disappearance of the relevant land rights and legal termination and affirmed as the soil directly controlled by the State. Criteria for determining the land has been abandoned, both under Customary Law, Islamic Law, Agrarian Law, Government Regulation No 36, 1998 and also No. 11, 2010 is substantially the same which includes wasteland Object land rights, land rights and management that have a basic mastery land; These lands are not cultivated, not utilized or not utilized in accordance with the circumstances, or the nature and purpose of the rights or basic mastery Therefore land should be maintained. To determine whether a field or farm land has been declared abandoned, the only criterion according to customary law used a specific period.
\end{abstract}

Keywords: Wasteland, State, Rights Holders, A Result Of Law, Land Tenure

\section{Abstrak}

Ketika Negara memberikan hak kepada orang atau badan hukum selalu diiringi kewajiban-kewajiban yang ditetapkan dalam UUPA dan surat keputusan pemberian haknya. Karena itu Pemegang Hak dilarang menelantarkan tanahnya, dan jika Pemegang Hak menelantarkan tanahnya maka UUPA telah mengatur akibat hukumnya yaitu hapusnya hak atas tanah yang bersangkutan dan pemutusan hubungan hukum serta ditegaskan sebagai tanah yang dikuasai langsung oleh Negara. Kriteria untuk menentukan tanah telah diterlantarkan, baik berdasarkan Hukum Adat, Hukum Islam, UUPA, PP No 36 Th 1998 maupun juga PP No 11 Th 2010 secara substansial adalah sama yaitu Obyek tanah terlantar meliputi hak atas tanah, Hak Pengelolaan dan tanah yang mempunyai dasar penguasaan atas tanah; Tanah-tanah tersebut tidak diusahakan, tidak dipergunakan atau tidak dimanfaatkan sesuai dengan keadaannya, atau sifat dan tujuan pemberian haknya atau dasar penguasaannya Oleh karena itu tanah harus dipelihara. Untuk menentukan apakah suatu bidang atau lahan tanah telah dinyatakan terlantar maka hanya menurut Hukum Adat digunakan kriteria jangka waktu tertentu.

Kata kunci: Tanah terlantar, Negara, Pemegang Hak, Akibat Hukum, Penguasaan Tanah

\section{Pendahuluan}

Negara menyelenggarakan pembangunan untuk kesejahteraan rakyat. Dalam realitasnya, dijumpai praktik di mana pemerintah berdasarkan keyakinannya secara yuridis dalam melaksanakan pembangunan tidak segan-segan lagi melakukan "kekerasan" terhadap rakyatnya yang secara yuridis memang banyak yang tidak mempunyai landasan hukum. Ketimpangan yang selalu terjadi yang biasanya selalu diikuti dengan konflik yaitu pendudukan tanah oleh bukan pemegang haknya untuk kemudian di- tanami dengan tanaman pangan semakin merebak. Obyeknyapun beragam meliputi tanah-tanah yang dikuasai oleh badan hukum maupun instansi pemerintah. ${ }^{1}$

Tanah adalah karunia Tuhan Yang Maha Esa bagi rakyat, bangsa dan Negara Indonesia, yang harus diusahakan, dimanfaatkan, dan dipergunakan untuk sebesar-besarnya kemakmuran rakyat. Saat ini tanah yang telah dikuasai

Maria SW Sumardjono, 2001, Kebijakan Pertanahan, antara Regulasi dan Implementasi, Kompas, Jakarta, hlm. 188 . 
dan/atau dimiliki baik yang sudah ada hak atas tanahnya maupun yang baru berdasar perolehan tanah di beberapa tempat masih banyak dalam keadaan terlantar, sehingga cita-cita luhur untuk meningkatkan kemakmuran rakyat tidak optimal. Oleh karena itu, perlu dilakukan penataan kembali untuk mewujudkan tanah sebagai sumber kesejahteraan rakyat, untuk mewujudkan kehidupan yang lebih berkeadilan, menjamin keberlanjutan sistem kemasyarakatan dan kebangsaan Indonesia, serta memperkuat harmoni sosial. Selain itu, optimalisasi pengusahaan, penggunaan, dan pemanfaatan semua tanah di wilayah Indonesia diperlukan untuk meningkatkan kualitas lingkungan hidup, mengurangi kemiskinan dan menciptakan lapangan kerja, serta untuk meningkatkan ketahanan pangan dan energi. ${ }^{2}$

Penelantaran tanah di pedesaan dan perkotaan, selain merupakan tindakan yang tidak bijaksana, tidak ekonomis (hilangnya peluang untuk mewujudnyatakan potensi ekonomi tanah), dan tidak berkeadilan, serta juga merupakan pelanggaran terhadap kewajiban yang harus dijalankan para Pemegang Hak atau pihak yang telah memperoleh dasar penguasaan tanah.

Dampak lain penelantaran tanah juga menjadi terhambatnya pencapaian berbagai tujuan program pembangunan, rentannya ketahanan pangan dan ketahanan ekonomi nasional, tertutupnya akses sosial-ekonomi masyarakat khususnya petani pada tanah, serta terusiknya rasa keadilan dan harmoni sosial.

Pada dasarnya Negara memberikan hak atas tanah atau Hak Pengelolaan kepada Pemegang Hak untuk diusahakan, dipergunakan, dan dimanfaatkan serta dipelihara dengan baik selain untuk kesejahteraan bagi Pemegang Haknya juga harus ditujukan untuk kesejahteraan masyarakat, bangsa dan negara. Tentu saja ketika Negara memberikan hak kepada orang atau badan hukum selalu diiringi kewajibankewajiban dalam surat keputusan pemberian haknya. Karena itu Pemegang Hak dilarang menelantarkan tanahnya, dan jika Pemegang

2 Penjelasan PP No 11 Tahun 2010 tentang Penertiban Dan Pendayagunaan Tanah Terlantar
Hak menelantarkan tanahnya maka UUPA (Undang Undang No 5 Th 1960) telah mengatur akibat hukumnya yaitu hapusnya hak atas tanah yang bersangkutan dan pemutusan hubungan hukum serta ditegaskan sebagai tanah yang dikuasai langsung oleh Negara.

UUPA (Undang Undang Pokok Agraria) sebagai dasar kebijakan pertanahan nasional yang memang sejak awal berciri populis, ${ }^{3}$ maka pemerintah yang mendapat legitimasi dari Negara berdasarkan Pasal 2 Ayat (2) UUPA mempunyai wewenang untuk:

a. mengatur dan menyelenggarakan peruntukan, penggunaan, persediaan dan pemeliharaan bumi, air dan ruang angkasa tersebut;

b. menentukan dan mengatur hubungan-hubungan hukum antara orang-orang dengan bumi, air, dan ruang angkasa;

c. menentukan dan mengatur hubungan-hubungan hukum antara orang-orang dan perbuatan-perbuatan hukum mengenai bumi, air dan ruang angkasa.

Ketentuan Pasal 2 ini kemudian dijadikan dasar bagi negara untuk mengatur pemberian hak-hak atas tanah seperti tersebut Pasal 4 Ayat (1) dan (2) UUPA. Pasal 4 menentukan

1) Atas dasar hak menguasai dari sebagai yang dimaksud dalam Pasal 2 ditentukan adanya macam-macam hak atas permukaan bumi, yang disebut tanah, yang dapat diberikan kepada dan dipunyai oleh orang-orang, baik sendirimaupun bersama-sama dengan orangorang lain serta badan-badan hukum;

2) Hak-hak atas tanah yang dimaksud dalam ayat 1 pasal ini memberi wewenang untuk mempergunakan tanah yang bersangkutan, demikian pula tubuh bumi dan air serta ruang yang ada di atasnya sekedar diperlukan untuk kepentingan yang langsung berhubungan dengan penggunaan tanah itu dalam batas-batas menurut undang-undang ini dan peraturan-peraturan hukum lain yang lebih tinggi.

Kemudian berdasarkan Pasal 16 UUPA diatur tentang macam-macam hak atas tanah

3 Maria SW Sumardjono, 2008, Tanah Dalam Prespektif Hak Ekonomi Sosial dan Budaya, Kompas, Jakarta, hlm. 36. 
yang diberikan negara adalah Hak Milik, Hak Guna Usaha (HGU), Hak Guna Bangunan (HGB), Hak Pakai, Hak Sewa, Hak Membuka Hutan, Hak Memungut Hasil Hutan dan hak-hak lain yang tidak termasuk dalam hak-hak tersebut di atas yang akan ditetapkan dengan undang undang serta hak-hak lain yang sifatnya sementara.

Jadi bagi tanah yang belum ada hak atas tanahnya, tetapi ada dasar penguasaannya, penggunaan atas tanah tersebut harus dilandasi dengan sesuatu hak atas tanah harus sesuai dengan ketentuan Pasal 4 juncto Pasal 16 UUPA. Oleh karena itu orang atau badan hukum yang telah memperoleh dasar penguasaan atas tanah, baik dengan pengadaan tanah itu dari hak orang lain, memperoleh penunjukan dari pemegang Hak Pengelolaan, karena memperoleh izin lokasi, atau memperoleh keputusan pelepasan kawasan hutan berkewajiban memelihara tanahnya, mengusahakannya dengan baik, tidak menelantarkannya, serta mengajukan permohonan untuk mendapatkan hak atas tanah. Meskipun yang bersangkutan belum mendapat hak atas tanah, apabila menelantarkan tanahnya maka hubungan hukum yang bersangkutan dengan tanahnya akan dihapuskan dan ditegaskan sebagai tanah yang dikuasai langsung oleh Negara.

Hal yang perlu ditegaskan disini karena bersifat sangat mendasar adalah bahwa dalam menggunakan atau mengambil manfaat macammacam hak atas tanah tersebut adalah prinsip yang sangat penting dalam Hukum Tanah kita yaitu bahwa semua hak atas tanah mempunyai fungsi sosial (Pasal 6 UUPA). Fungsi ini pada intinya memberikan pengaturan tentang larangan penggunaan tanah untuk semata-mata kepentingan perseorangan tanpa mengindahkan kepentingan masyarakat dan negara. Kepentingan masyarakat dan kepentingan perseorangan haruslah saling mengimbangi hingga akhirnya akan tercapai tujuan pokok yaitu kemakmuran, keadilan dan kebahagiaan bagi rakyat seluruhnya. Jadi yang perlu ditegaskan adalah bahwa pemanfaatan sumber daya agraria sebagaimana tertuang dalam Pasal 33 ayat (3) UUD
1945 yaitu untuk sebesar-barnya kesejahteraan rakyat.

Dalam rangka untuk mencapai tujuan tersebut maka UUPA juga mengatur berakhirnya hak-hak atas tanah yang antara lain karena diterlantarkan. Hak Milik berakhir karena ditelantarkan (Pasal 27), HGU (Pasal 34) dan HGB (Pasal 40) berakhir juga karena diterlantarkan. Hak Pakai dan hak-hak lain tidak ada ketentuan tentang berakhirnya karena diterlantarkan. Artinya, setiap pemberian hak oleh negara kepada perorangan atau badan-badan hukum haruslah bersama-sama dengan kewajiban-kewajiban yang harus dilaksanakan oleh pemegang hak sesuai dengan peruntukan dan persyaratan sebagaimana ditetapkan dalam keputusan pemberian haknya. ${ }^{4}$

Oleh sebab itu, penelantaran tanah harus dicegah dan ditertibkan untuk mengurangi atau menghapus dampak negatifnya. Dengan demikian pencegahan, penertiban, dan pendayagunaan tanah terlantar merupakan langkah dan prasyarat penting untuk menjalankan programprogram pembangunan nasional, terutama di bidang agraria yang telah diamanatkan oleh Undang-Undang Dasar Negara Republik Indonesia Tahun 1945, Peraturan Dasar Pokok-Pokok Agraria, serta Rencana Pembangunan Jangka Panjang Nasional.

Sebenarnya telah banyak dibuat peraturan tentang tanah terlantar. Antara lain pada tahun 1973 pernah dikeluarkan Keputusan Menteri Dalam Negeri No 88 Tahun 1973 tentang Penguasaan Tanah Perkebunan Terlantar dan atau Diterlantarkan Di Daerah Propinsi Jawa Barat, PP No 36 Th 1998 tentang Penerbitan dan Pendayagunaan Tanah Terlantar yang didikuti dengan SK Kepala BPN No 24 Th 2002 tentang Pelaksanaan PP No 36 Th 1998. Berdasarkan Keputusan Kepala BPN No 24 Th 2002 tersebut maka diperintahkan kepada jajaran BPN yang berada di bawah koordinasinya yang ada di Kantor Wilayahnya, Dikantor Kota Madya/Kabupaten untuk melakukan identifikasi dan dalam waktu tertentu membentuk Tim

Suhariningsih, 2009, Tanah Terlantar, Jakarta: Penerbit Prestasi Pustaka Raya, hlm. 14. 
Penilai dalam rangka mentertibkan tanah-tanah terlantar. Pekerjaan melakukan identifikasi bukanlah pekerjaan yang mudah karena memerlukan kejelasan konsep dan kriteria tanah terlantar. ${ }^{5}$ Kemudian karena PP No 36 Th 1998 sudah tidak dapat lagi dijadikan acuan penyelesaian penertiban dan pendayagunaan tanah terlantar dan dikatakan menurut Usep Setiawan Ketua KPA (Komite Pembaharuan Agraria) sudah tidak efektif di lapangan dan banyak yang menyulitkan pada saat implementasinya sehingga perlu dilakukan penggantian maka pada era Reformasi terakhir pada tanggal 22 Januari telah dikeluarkan PP No 11 Th 2010. Pada saat Peraturan Pemerintah ini mulai berlaku, Peraturan Pemerintah Nomor 36 Tahun 1998 tentang Penertiban dan Pendayagunaan Tanah Terlantar dan peraturan pelaksanaannya dicabut dan dinyatakan tidak berlaku. Berdasarkan uraian latar belakang tersebut di atas maka tulisan ini dimaksudkan untuk mengetahui kriteria tanah yang diterlantarkan menurut Hukum Tanah Nasional.

\section{Pembahasan}

Hukum agraria yang berlaku atas bumi, air dan ruang angkasa ialah hukum adat sepanjang tidak bertentangan dengan kepentingan nasional dan negara, yang berdasarkan atas persatuan bangsa, dengan sosialisme Indonesia serta dengan peraturan-peraturan yang tercantum dalam undang-undang ini dan dengan peraturan perundangan lainnya, serta dengan mengindahkan unsur-unsur yang bersandar pada hukum agama. Demikian dinyatakan dalam Pasal 5 UUPA. Hukum adat dijadikan dasar dikarenakan hukum tersebut dianut oleh sebagian besar rakyat Indonesia sehingga Hukum Adat mempunyai kedudukan yang istimewa dalam pembentukan Hukum Agraria. ${ }^{6}$ Memperhatikan ketentuan pasal ini maka untuk itu perlu kiranya mengetahui batasan tanah terlantar menurut Hukum Adat.

Berdasarkan kajian atas keragaman arti tanah terlantar menurut Hukum Adat maka da-

Ibid hal 20

Urip Santoso, 2005, Hukum Agraria dan Hak-Hak Atas Tanah, Jakarta: Kencana Perdana Media Grup, hlm.6465. pat diambil kesimpulan bahwa yang dimaksud tanah terlantar adalah tanah yang pernah dibuka, dikerjakan oleh pemilik/penggarapnya sampai 1 kali atau 2 kali panen, kemudian ditinggalkan oleh pemiliknya dalam waktu tertentu sampai menjadi hutan kembali. Secara yuridis kemudian tanah ini kembali pada hak ulayatnya. ${ }^{7}$ Jadi unsur tanah disebut terlantar menurut Hukum Adat :

a. Penggarap pernah membuka tanah ulayat;

b. Penggarap mengerjakan/menggarap sampai 1 kali atau 2 kali panen;

c. Penggarap meninggalkan dalam waktu tertentu sehingga menjadi hutan kembali;

d. Tanah kembali menjadi milik masyarakat hukum adat.

Dari pengertian tanah terlantar menurut Hukum Adat ini maka tanah dikatakan telah diterlantarkan kalau kriterianya adalah tanah telah dengan sengaja tidak dikerjakan oleh penggarapnya/pemiliknya dalam waktu tertentu sehingga kemudian menjadi belukar kembali. Untuk mengukur apakah tanah sudah dapat dikatakan diterlantarkan ataukah belum menurut Hukum Adat adalah dengan melihat secara nyata/konkrit apakah tanah tersebut dalam kenyataannya dengan sengaja tidak digarap atau dikerjakan secara aktif oleh penggarap/ pemiliknya. Jadi dalam menentukan sudah diterlantarkan ataukah belum tidak digantungkan pada jangka waktu tertentu tetapi hanya dengan melihat kenyataan jika tanah dibiarkan membelukar kembali karena sudah tidak untuk ditanami kembali maka hal ini sudah dapat dikualifikasi sebagai telah diterlantarkan.

Dalam Pasal 5 UUPA, selain Hukum Agraria mendasarkan diri pada Hukum Adat juga harus mengindahkan unsur-unsur yang bersandar pada Hukum Agama. Menurut Hukum Islam tanah terlantar dalam Islam dikenal dengan tanah mati atau ihya al-mawat. AlMawat secara etimologi berarti yang mati atau lawan dari hidup. Al-mawat memiliki arti yaitu sesuatu yang tidak mempunyai roh atau tanah yang tidak berpenghuni atau tidak seorangpun memanfaatkannya. Al-Mawat berarti sesuatu yang tidak mempunyai roh dan tanah tidak

Suhariningsih, op.cit, hlm. 245. 
berpenghuni atau berarti sesuatu yang tidak mempunyai roh, juga berarti tanah yang tidak dimiliki serta tidak dimanfaatkan. Dalam buku Nataij al-Afkar, tanah mati yaitu tanah yang tidak dimanfaatkan karena ketidakadaan air, serta susah pula memanfaatkannya, tidak dimiliki, atau terdapat atas tanah tersebut hak milik, tetapi tidak diketahui pemiliknya serta jauh dari perkampungan. ${ }^{8}$

Secara terminologi terdapat beberapa pengertian al-mawat yang drkemukakan para ulama fikih, ulama Syafi'iyah, Malikiyah dan Hambaliah mengemukakan definisi al-mawat dalam persepsi tentang tanah yang tidak dimiliki dan tidak dimanfaatkan oleh seseorang. Ulama Syafi'iyah mendefinisikan sebagai lahan yang belum digarap orang dan tidak pula terlarang untuk digarap baik lahan itu jauh dari pemukiman maupun dekat. Pengikut mazhab Hambali menyebutkan bahwa al-mawat adalah lahan yang tidak diketahui pemiliknya. Di kalangan mazhab Hanafi, tanah al-mawat tidak hanya diartikan sebagai tanah yang tidak dimiliki dan tidak dimanfaatkan, tetapi tanah itu disyaratkan berada di luar perkampungan penduduk. Sebagaimana pengertian al-mawat yang diungkapkan oleh Hanafiyah bahwa tanah yang berada di luar perkampungan, tidak dimiliki oleh siapapun, tidak pula terdapat hak khusus atasnya. ${ }^{9}$

Berdasarkan definisi al-mawat yang dikemukakan oleh fuqaha di atas, maka kriteria tanah yang digolongkan menjadi tanah terlantar menurut Hukum Islam adalah:

a. Tanah yang tidak dimiliki oleh seseorang atau tanah yang tidak terdapat hak milik atasnya, baik hak milik orang Islam maupun hak milik non nuslim.

b. Tanah yang tidak digarap. Lahan yang tidak digarap dapat dibuktikan dengan tandatanda pada lahan tersebut seperti pemagaran, bekas penggarapan dan tanda-tanda lainnya yang biasa dipakai oleh masyarakat setempat.

\footnotetext{
8 Pangiuk Ambok, “ Tanah Terlantar Dalam Hukum dan Kemaslahatan", http://kontekstualita.com. Diakses tgl 21 April 2010.

$9 \quad$ Ibid
}

c. Tanah yang berada jauh di luar perkampungan.

Dengan perkataan lain sebetulnya menurut Hukum Islam semua tanah yang tidak dimiliki oleh seseorang baik orang Islam maupun non Islam dan tidak dimanfaatkan oleh sebab apapun juga maka dapat digolongkan sebagai tanah yang terlantar. Jadi pada prinsipnya Hukum Islam memandang kalau tanah tidak dimanfaatkan maka tanah tersebut digolongkan sebagai tanah yang terlantar.

Selanjutnya berdasarkan UUPA maka ada beberapa azas yang perlu diperhatikan dalam masalah penelantaran tanah. Dinyatakan dalam Pasal 6 UUPA bahwa semua hak atas tanah mempunyai fungsi sosial. Hal ini bermakna bahwa penggunaan tanah harus disesuaikan dengan keadaannya dan sifat haknya sehingga bermanfaat baik bagi kesejahteraan dan kebahagiaan yang mempunyainya maupun bermanfaat bagi masyarakat dan negara. ${ }^{10}$

Untuk itu hak atas tanah apapun yang dipunyai seseorang/badan hukum tidaklah dapat dibenarkan bahwa tanahnya itu dipergunakan atau tidak dipergunakan semata-mata hanya untuk kepentingan pribadinya apalagi sampai merugikan kepentingan umum. Pemanfaatan ataupun penggunaan tanah oleh orang/ badan hukum sebenarnya adalah untuk mencapai kesejahteraan rakyat. Sehubungan dengan hal ini maka ditentukan dalam Pasal 15 UUPA bahwa :

Memelihara tanah, termasuk menambah kesuburannya serta menjegah kerusakannya adalah kewajiba tiap- tiap orang, badan hukum atau instansi yang mempunyai hubungan hukum dengan tanah itu, dengan memerhatikan pihak yang ekonomis lemah.

Memang seharusnya tanah dipelihara agar baik agar bertambah subur dan di cegah kerusakannya. Kesuburan tanah mudah berkurang dan tanahpun mudah menjadi rusak jika pengunaannya tidak teratur, padahal seluruh kehidupan manusia di bumi ini menurut para ahli tergantung pada lapisan bumi yang tebalnya

\footnotetext{
10 Arie Sukanti Hutagalung dan Markus Gunawan, 2008, Kewenangan Pemerintah di Bidang Pertanahan, Jakarta: Rajawali Pers, hlm. 70.
} 
tidak lebih dari hanya $20 \mathrm{~cm}$ saja. Oleh karena itu ketentuan Pasal 15 tersebut di sertai pula suatu sanksi pidana. Menurut Pasal 52 ayat 1 barang siapa dengan sengaja melanggar ketentuan dalam Pasal 15 itu pidana dengan hukuman kurangan selama-lamanya 3 bulan dan/ atau denda setinggi-tingginya Rp 10.000,.-

Soal ini bersangkutan dengan apa yang disebut masalah "land utilazation" dan "soil conservation" tidak hanya bertujuan mencegah terjadinya kerusakan dalam penggunaannya tetapi juga dimana mungkin memperbaiki sumber-sumber alam yang rusak sebagai akibat penggunan yang salah.Sumber-sumber alam itu ada yang "renewable" atau terbaharukan, tetapi sumber-sumber alam yang "non renewable" (bahan-bahan galian). Mengenai sumbersumber alam yang "non renewable" conservation eksploitasi secara teratur dan pencegahan pemborosan penggunaannya. Dari sudut strategi, conservation " non renewable" (tidak terbaharukan) resources merupakan penangguhan eksploitasi endapan-endapan sebagai cadangan di waktu perang. ${ }^{11}$

Selanjutnya ketentuan mengenai tanah terlantar dalam Pasal 27, 34 dan 40 UUPA dengan redaksi yang sama dinyatakan bahwa Hak Milik, HGU dan HGB dapat hapus karena diterlantarkan. Tanah diterlantarkan kalau dengan sengaja tidak dipergunakan sesuai dengan keadaannya atau sifat dan tujuan daripada haknya Penjelasan Pasal 27 UUPA). Dengan demikian hapusnya hak-hak tersebut karena hukum yaitu tidak dipenuhinya suatu kewajiban atau dilanggarnya suatu larangan. Dalam hal penelantaran tanah ini maka tampak adanya kesengajaan dari pemegang hak/subyek hak tidak menggunakan sesuai dengan tujuan dan sifat daripada haknya.

Melihat rumusan tanah terlantar dalam UUPA yang masih begitu abstrak dan juga mengingat UUPA adalah merupakan undang-undang pokok serta mencermati fenomena yang terjadi akan banyaknya tanah-tanah yang terlantar maka tentu saja diperlukan peraturan yang bersifat operasional. Untuk itu pemerintah

11 Budi Harsono, 1997, Hukum Agraria Indonesia, Jakarta: Jambatan, hlm. 271. mengeluarkan Peraturan Pemerintah No 36 Th 1998 tentang Penertiban dan Pendayagunaan Tanah Terlantar.

Dalam Pasal 1 ayat (5) Peraturan Pemerintah No 36 Th 1998 dinyatakan bahwa Tanah terlantar adalah tanah yang diterlantarkan oleh pemegang hak atas tanah, pemegang hak pengelolaan atau pihak yang telah memperoleh dasar penguasaan atas tanah, tetapi belum memperoleh hak atas tanah sesuai ketentuan peraturan perundang-undangan yang berlaku.

Ketentuan hal ini sebetulnya juga telah ditentukan dalamUUPA Pasal 27, 34 dan 40 UUPA yaitu bahwa Hak Milik, HGU, HGB dapat dinyatakan sebagai tanah terlantar dan jatuh menjadi tanah negara apabila tanah tersebut dengan sengaja tidak dipergunakan oleh pemegang haknya sesuai dengan keadaannya atau sifat dan tujuan haknya atau tidak dipelihara dengan baik.

Memperhatikan ketentuan di atas maka dapat disimpulkan bahwa tanah terlantar terjadi karena ada faktor kesengajaan (kata "diterlantarkan" awalan di dan akhiran kan) dari pemegang hak atas tanah (Hak Milik, HGU, HGB ataupun Hak Pakai) atau pemegang Hak Pengelolaan atau hak-hak lain yang terbatas yang diberikan Pemerintah tidak menggunakan atau berbuat sesuatu terhadap tanah yang bersangkutan. Hal ini kemudian dipertegas lagi dengan ketentuan Pasal $3 \mathrm{~s} / \mathrm{d}$ Pasal 8 Peraturan Pemerintah No 36 Th 1998. Pasal 3 menentukan Tanah Hak Milik, HGU, HGB atau Hak Pakai dapat dinyatakan sebagai tanah terlantar apabila tanah tersebut dengan sengaja tidak dipergunakan oleh pemegang haknya sesuai dengan keadaannya, tidak dipergunakan oleh pemegang haknya sesuai dengan keadaannya atau sifat dan tujuan haknya atau tidak dipelihara dengan baik.

\section{Pasal 4 menentukan bahwa}

Tanah Hak Milik, Hak Guna Bangunan atau Hak Pakai yang tidak dimaksudkan untuk dipecah menjadi beberapa bidang tanah dalam rangka penggunaannya tidak dipergunakan sesuai dengan keadaannya atau sifat dan tujuan haknya sebagaimana dimaksud dalam Pasal 3, apabila tanah tersebut tidak dipergunakan sesuai 
dengan peruntukannya menurut Rencana Tata Ruang Wilayah yang berlaku pada waktu permulaan penggunaan atau pembangunan fisik di atas tanah tersebut.

\section{Pasal 5 menentukan bahwa}

Tanah HGU tidak dipergunakan sesuai keadaan atau sifat dan tujuan haknya sebagaimana dimaksud dalam Pasal 3, apabila tanah itu tidak diusahakan sesuai dengan kriteria pengusahaan tanah pertanian yang baik sesuai ketentuan peraturan perundang-undangan yang verlaku.

\section{Pasal 6 menentukan bahwa}

Tanah Hak Guna Bangunan atau Hak Pakai yang dimaksudkan untuk dipecah menjadi beberapa bidang tanah dalam rangka penggunaannya tidak dipergunakan sesuai dengan keadaannya atau sifat dan tujuan haknya sebagaimana dimaksud dalam Pasal 3, apabila tanah tersebut tidak dipecah dalam rangka pengembangannya sesuai dengan rencana kerja yang telah disetujui oleh instansi yang verwenang.

\section{Pasal 7 menyatakan:}

Tanah Hak Pengelolaan dapat dinyatakan sebagai tanah terlantar, apabila kewenangan hak menguasai dari Negara atas tanah tersebut tidak dilaksanakan oleh pemegang Hak Pengelolaan sesuai tujuan pemberian pelimpahan kewenangan tersebut.

Dari bunyi ketentuan pasal-pasal tersebut maka menurut PP No 36 Th 1998 maka kriteria tanah dengan status Hak Milik, HGU, HGB, Hak pakai dan Hak Pengelolaan adalah:

1. Apabila tanah tersebut dengan sengaja tidak dipergunakan sesuai dengan keadaannya atau sifatnya;

2. Apabila tanah tersebut tidak dipergunakan sesuai dengan tujuan pemberian haknya;

3. Tanah tersebut tidak dipelihara dengan baik;

4. Khusus untuk tanah Hak Pengelolaan, apabila kewenangan hak menguasai dari Negara atas tanah tersebut tidak dilaksanakan oleh pemegang hak pengelolaan sesuai tujuan pemberian pelimpahan kewenangan tersebut.

Pada dasarnya tanah terlantar yang dimaksud adalah tanah negara yang ada hak penggunaannya, tapi tidak dimanfaatkan. Jadi dapat ditarik kesimpulan bahwa tanah terlantar terjadi apabila pemegang atau yang menguasai hak atas tanah atau pemegang hak pengelolaan tidak melakukan aktivitas terhadap tanah tersebut. $^{12}$

Kemudian hal yang masih belum jelas dari ketentuan pasal-pasal tersebut adalah mengenai perumusan apa yang dimaksud dengan tanah yang tidak dipergunakan sesuai dengan keadaannya atau sifatnya ataupun tanah tidak dipergunakan sesuai dengan tujuan pemberian haknya. Menyadari hal ini dan juga yang lebih penting lagi karena Pemerintah kesulitan menertibkan tanah terlantar karena PP No 36 Tahun 1998 tidak efektif di lapangan dan sulit dalam implementasinya. Salah satu akibatnya, niat pemerintah untuk mulai menjalankan reforma agraria menjadi terkendala, salah satunya karena objek tanah yang dapat didistribusikan bagi kepentingan rakyat miskin, penguasaannya masih berada di berbagai pihak yang menelantarkan tanah. Pendek kata, keberadaan tanah terlantar dalam skala yang luas menjadi ganjalan penting bagi guliran reforma agraria. Menurut kalangan pecinta pembaruan agraria, PP yang terdahulu (PP 36/1998) tidak cukup kuat menertibkan tanah terlantar yang ada. Bahkan disinyalir sebagai peraturan yang melindungi tanah terlantar tidak bisa ditertibkan. ${ }^{13}$

Atas dasar pertimbangan tersebut dan juga untuk menghindari implikasi yang menimbulkan kesenjangan sosial, ekonomi, dan mewujudkan kesejahteraan rakyat, serta menurunkan kualitas lingkungan, maka sebagai salah-satu Rencana Aksi yang harus diselesaikan dalam Program 100 Hari Kabinet Indonesia Bersatu II, Pemerintah menerbitkan Peraturan Pemerintah Nomor 11 Tahun 2010 tentang Penertiban dan Pendayagunaan Tanah Terlantar

\footnotetext{
12 Supriadi, 2006, Hukum Agraria, Sinar Grafika, Jakarta, hlm. 124

13 Iwan Nurdin, Setelah PP Tanah Terlantar disyahkan, Http//M, diakses tanggal 21 April 2010.
} 
(PP PPTT) Lembaran Negara Republik IndonesiaTahun 2010 Nomer 16 dan Tambahan Lembaran Negara Republik Indonesia Nomer 5098, yang ditandatangani oleh Presiden Dr. H. Susilo Bambang Yudhoyono pada tanggal 22 Januari 2010, untuk dijadikan acuan penertiban dan pendayagunaan tenah terlantar guna penyelesaian dampak tersebut di atas. ${ }^{14}$

Pengertian tanah terlantar dalam PP No 10 Tahun 2010 sebagaimana produk peraturan lainnya dapat dilihat pada Pasal 2, menentukan

Obyek penertiban tanah terlantar meliputi tanah yang sudah diberikan hak oleh Negara berupa Hak Milik, Hak Guna Usaha, Hak Guna Bangunan, Hak Pakai, dan Hak Pengelolaan, atau dasar penguasaan atas tanah yang tidak diusahakan, tidak dipergunakan, atau tidak dimanfaatkan sesuai dengan keadaannya atau sifat dan tujuan pemberian hak atau dasar penguasaannya.

Pasal 3, menyatakan :

Tidak termasuk obyek penertiban tanah terlantar sebagaimana dimaksud dalam Pasal 2 adalah:

a. tanah Hak Milik atau Hak Guna Bangunan atas nama perseorangan yang secara tidak sengaja tidak dipergunakan sesuai dengan keadaan atau sifat dan tujuan pemberian haknya; dan

b. tanah yang dikuasai pemerintah baik secara langsung maupun tidak langsung dan sudah berstatus maupun belum berstatus Barang Milik Negara/ Daerah yang tidak sengaja tidak dipergunakan sesuai dengan keadaan atau sifat dan tujuan pemberian haknya.

Jadi pada dasarnya tanah terlantar yang dimaksud adalah tanah negara yang ada hak penggunaannya tetapitidak dimanfaatkan oleh pemegang haknya. Berdasarkan pengertian tersebut maka kriteria untuk menentukan tanah dikualisir sebagai telah diterlantarkan menurut PP No 11 Th 2010 adalah :

1. Obyek tanah terlantar meliputi hak atas tanah, Hak Pengelolaan dan tanah yang mempunyai dasar penguasaan atas tanah;

14 Ahmad Redi, 2010, "Reforma Agraria Melalui Pertiban Dan Pendayagunaan Tanah Terlantar", http://Ahmad Redi 2003.blogspot.com. diakses tanggal 19 April 2010
2. Tanah yang tidak diusahakan, tidak dipergunakan atau tidak dimanfaatkan;

3. Yang sesuai dengan keadaannya, atau sifat dan tujuan pemberian haknya atau dasar penguasaannya;

4. Tidak termasuk tanah terlantar adalah:

a. Tanah Hak Milik atau HGB atas nama perseorangan yang secara tidak sengaja tidak dipergunakan sesuai dengan keadaan atau sifat dan tujuan pemberian haknya; dan

b. tanah yang dikuasai pemerintah baik secara langsung maupun tidak langsung dan sudah berstatus maupun belum berstatus Barang milik Negara/Daerah yang tidak sengaja tidak dipergunakan sesuai dengan keadaan atau sifat dan tujuan pemberian haknya.

Dalam penjelasan Pasal 3 dijelaskan bahwa yang dimaksud dengan "tidak sengaja tidak dipergunakan sesuai dengan keadaan atau sifat dan tujuan pemberian haknya" dalam ketentuan ini adalah karena Pemegang Hak perseorangan dimaksud tidak memiliki kemampuan dari segi ekonomi untuk mengusahakan, mempergunakan, atau memanfaatkan sesuai dengan keadaannya atau sifat dan tujuan pemberian haknya. Yang dimaksud dengan "tidak sengaja tidak dipergunakan sesuai dengan keadaan atau sifat dan tujuan pemberian haknya" dalam ketentuan ini adalah karena keterbatasan anggaran negara atau daerah untuk mengusahakan, mem-pergunakan, atau memanfaatkan sesuai dengan keadaannya atau sifat dan tujuan pemberian haknya.

Keberadaan PP No.11 Th 2010 dinilai sangat penting dalam merestrukturisasi pemilikan dan penguasaan tanah lebih adil bagi rakyat. Tanah terlantar antara lain untuk masyarakat dalam rangka reformasi agraria, untuk kepentingan strategi negara dan pemerintah di antaranya untuk ketahanan pangan, ketahanan energi dan pengembangan perumahan rakyat.

Setelah ditetapkan sebagai bagian dari program 100 hari pemerintahan SBY-Boediono, PP ini memang pada akhirnya disyahkan dengan segala kekurangannya. Namun demikian 
ada beberapa hal yang perlu dikritisi antara lain:

1. PP ini tidak berani menyentuh tanah-tanah yang terkait dengan pemerintah dan BUMN, tanpa membedakan apakah sudah mendapat hak atau belum. Tanah-tanah tersebut dikecualikan dari penelantaran tanah. Jadi asset negara/pemerintah itu tidak bisa dikategorikan terlantar;

2. PP ini tetap tidak berani menjangkau kawasan hutan dan tambang. Jadi, hanya wilayah diluar kawasan tersebut;

3. Setelah ditertibkan tanah-tanah tersebut dapat dijadikan objek pembaruan agraria. Padahal, peraturan tentang atau PP tentang Reforma Agraria belum ada. ${ }^{15}$

Mengingat akan arti pentingnya maka tentu saja PP ini perlu segera ditindak lanjuti dengan peraturan pelaksanaan yang lebih detail seperti misalnya mengenai penentuan kriteria suatu tanah dikualisir sebagai tanah terlantar apakah hanya memperhatikan normanya saja tanpa melihat hal-hal yang secara khusus yang terjadi di lapangan.

\section{Penutup}

\section{Simpulan}

1. Kriteria untuk menentukan tanah atau lahan tanah telah diterlantarkan, baik berdasarkan Hukum Adat, Hukum Islam, UUPA, PP No 36 Th 1998 maupun juga PP No 11 Th 2010 secara substansial adalah sama yaitu :

a. Obyek tanah terlantar meliputi hak atas tanah, Hak Pengelolaan dan tanah yang mempunyai dasar penguasaan atas tanah;

b. Tanah-tanah tersebut tidak diusahakan, tidak dipergunakan atau tidak dimanfaatkan sesuai dengan keadaannya, atau sifat dan tujuan pemberian haknya atau dasar penguasaannya;

c. Oleh karena itu tanah harus dipelihara.

2. Untuk menentukan apakah suatu bidang atau lahan tanah telah dinyatakan terlantar maka hanya menurut Hukum Adat digunakan kriteria jangka waktu tertentu.

\section{Saran}

1. Perlu segera ditindak lanjuti dengan peraturan pelaksanaan yang lebih detail seperti misalnya mengenai penentuan kriteria suatu tanah dikualisir sebagai tanah terlantar apakah hanya memperhatikan normanya saja tanpa melihat hal-hal yang secara khusus yang terjadi di lapangan.

2. Agar masyarakat dalam artian yang luas bisa segera mengetahui akan adanya PP No 11 Th 2010 maka perlu segera diadakan sosialisasi dengan melalui media TV, Koran, Majalah ataupun juga terjun langsung ke masyarakat dengan cara penyuluhan hukum. 